\title{
4305 陰関数曲面による形状表現の利点
}

\author{
大 竹豊
}

Advantages of Shape Representation using Implicit Surfaces

Yutaka Ohtake

\section{概 要}

近年, ポリゴンメッシュや点群により定義される曲面 データを陰関数曲面による表現に変換する方法が盛んに 研究されている. 本講義では, 陰関数曲面で形状を表現す ることにより,どのような利点があるかをまとめる.

\section{1.はじめに}

曲面上の点データから, 陰関数を用いて曲面を再構成す る方法が近年盛んに研究されてきている. Fig.1に, 点デー タから計算された陰関数曲面の例を示す.ここで，目的 の曲面は空間の座標值を引数とするスカラ関数 $f(x, y, z)$ のゼロレベルで表される. また, $f(x, y, z)$ の符号により, 曲面の内外を判定することも可能である.
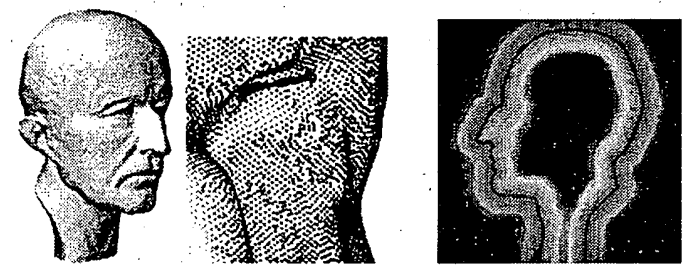

Figure 1: A conversion from points to an implicit surface. Left and middle: Points. Right: Values of the implicit function obtained by ${ }^{3)}$.

代表的な方法としては，Radial Basis Function (以下 RBF) を用いる方法 ${ }^{5) .7)}$ がよく知られているが, 密な線型 方程式を解く必要があるため, 入力点数の限界は多くても 1,2 万程度である. そこで1)においては, Fast Multi-pole Method と呼ばれる方法で数百万点を扱えることを可能

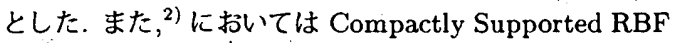
(以下 CSRBF) を用いて解くべき線形方程式を疎にし，同 様に大規模な点データを扱うことが可能である. さらに， CSRBF を多重スケール化することにより ${ }^{4)}$, 入力点に不 均一性や久落部分があっても，曲面を上手く再構成する 手法も開発されている: ‘たた, RBF を基にした方法では, 大域的な方程式を解く必要があるため，入力点数に制約が

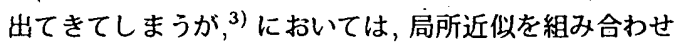
る方法である Partition of Unityを使うことにより, 入

\section{†理化学研究所}

RIKEN
力点の制約をなくしている. また, 鋭利な特街なども局所 近似を適合させることにより可能としている. 他には, 入 力を点群ではなくポリゴンとする手法も最近開発されて (る6).

方講義では, 上記の方法による, 点やポリゴンなどによ る表面データから陰関数表現への変換の方法が, どのよ うな場面で応用可能かどうかを述べる.

\section{2. 曲面データの修復}

陰関数の符号により, 空間は内側と外側に分けられ, 更 に内側と外側の間に曲面が存在する. 従っで陰関数曲面 は閉じた曲面を表す. Fig. 2 に示すように, 入力データに 欠落があうた際にも, 陰関数曲面をフィッテングすること により, 久落部分を修復することが可能である.

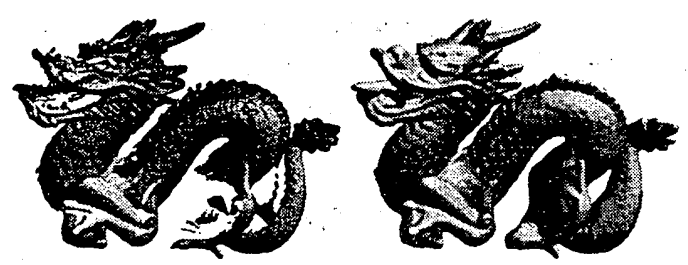

Figure 2: Repairing missing parts of a surface. Left: Points obtained from several rage images. Right: A reconstructed surface using ${ }^{4}$.

\section{CSG による形状操作}

関数の符号により内外が判定されるので, ブール操作 が非常に簡単に行える. また, ゼロレベルの近くの関数值 を用いての，形状のブレンディング操作なども可能であ る. Fig. 3 に例を示す.
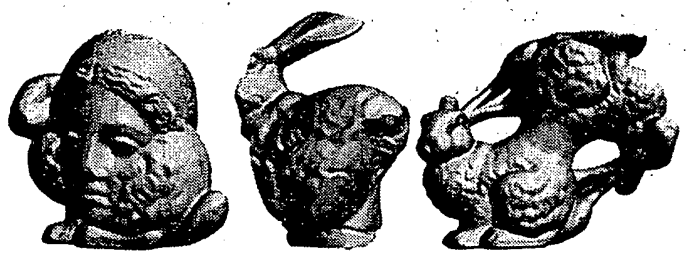

Figure 3: Shape editing using implicit functions. Left and middle: Boolean operations (union and intersection). Right: Blending.

[No.04-40] 日本機械学会第 17 回計算力学講演会講演論文集 [2004-11.18 20 -仙台市 ] 


\section{4. 曲面のオフセット}

陰関数により定義される曲面は，ゼロレベルだけでな く，ゼロ以外の他の值でも良い，特に，陰関数が符号付距 離場を近似している場合には, 形状のオフセットを簡単 に計算することができる. Fig. 4 に 2 次元と 3 次元の例 を示す

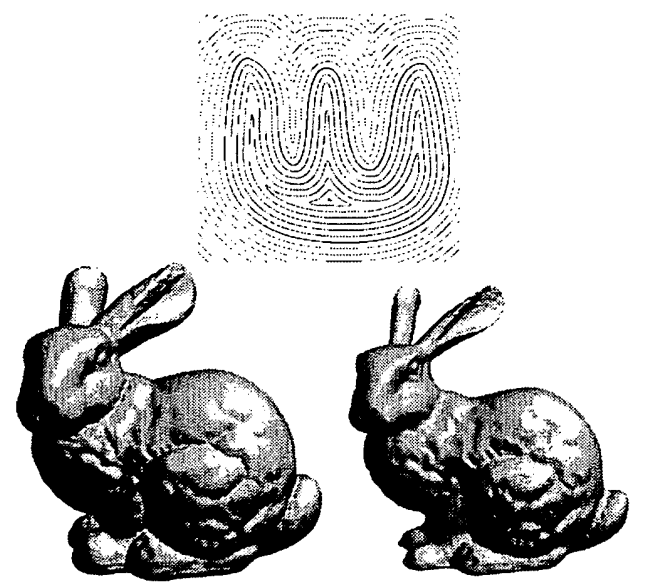

Figure 4: Offsetting curves and surfaces. Left: A set of offsetting curves obtained by an implicit function. Middle and right: Outer and inner offset surfaces.

\section{5. 測定データのノイズ除去}

レーザースキャンや CT スキャンによるデータは，測 定誤差によるノイズを含む. Fig. 5 に示すように，適切な 陰関数フィティングを行うことによりノイズを除去し，滑 らかな近似曲面を得ることが可能である.

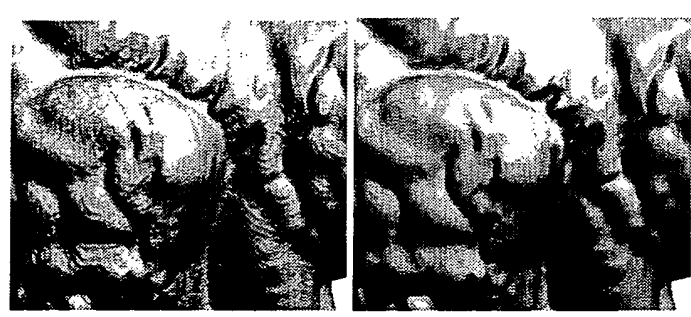

Figure 5: Smoothing a noisy surface. Left: A part of the isosurface obtained from CT data. Right: A smooth approximation of the noisy surface.

\section{6. 曲面上の微分值の算出}

曲面上の微分值は，法線や曲率を計測する上で非常に重 要な值である. 陰関数は, 解析的な関数により定義される ので，微分もまた解析的に行うことが可能である. Fig. 6 で分かるように，三角メッシュ上を用いて有限差分法で計
算するよりも安定して微分值を計算することができる．
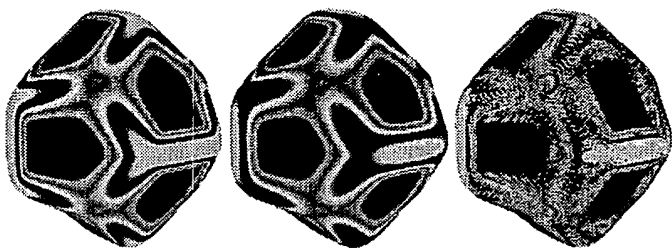

Figure 6: Curvature estimation. Left: Exact values of the maximum principal curvature on an analytically defined surface. Middle: Curvature values are estimated via implicit surface fitting. Right: Curvature values are estimated using a finite difference approach on the triangle mesh.

\section{参考 文 献}

1) J. C. Carr, R. K. Beatson, J. B. Cherrie, T. J. Mitchell, W. R. Fright, B. C. McCallum, and T. R. Evans. Reconstruction and representation of $3 \mathrm{D}$ objects with radial basis functions. In Proc. of ACM SIGGRAPH 2001, pages 67-76, August 2001.

2) B. S. Morse, T.S. Yoo, P. Rheingans, D. T. Chen, and K. R. Subramanian. Interpolating implicit surfaces from scattered surface data using compactly supported radial basis functions. In Shape Modeling International 2001, pages 89-98, Genova, Italy, May 2001.

3) Y. Ohtake, A. Belyaev, M. Alexa, G. Turk, and H.-P. Seidel. Multi-level partition of unity implicits. ACM Trans. on Graphics, 22(3):463-470, July 2003. Proc. of ACM SIGGRAPH 2003.

4) Y. Ohtake, A. G. Belyaev, and H.-P. Seidel. A multi-scale approach to 3D scattered data interpolation with compactly supported basis functions. In Shape Modeling International 2003, pages 153161, Seoul, Korea, May 2003.

5) V. V. Savchenko, A. A. Pasko, O. G. Okunev, and T. L. Kunii. Function representation of solids reconstructed from scattered surface points and contours. Computer Graphics Forum, 14(4):181188,1995

6) Chen Shen, James F. O'Brien, and Jonathan R. Shewchuk. Interpolating and approximating implicit surfaces from polygon soup. In Proceedings of ACM SIGGRAPH 2004. ACM Press, August 2004.

7) G. Turk and J.O'Brien. Shape transformation using variational implicit surfaces. In Proceedings of ACM SIGGRAPH 1999, pages 335-342, August 1999. 